\title{
Interactive Effects of 1-MCP and Temperature on 'Elberta' Peach Quality
}

\author{
X. Fan ${ }^{1}$, L. Argenta ${ }^{2}$, and J.P. Mattheis ${ }^{3}$ \\ U.S. Department of Agriculture, ARS Tree Fruit Research Laboratory, 1104 \\ N. Western Avenue, Wenatchee, WA 98801
}

Additional index words. ethylene, respiration, firmness, tritatable acidity, internal browning, extractable juice

\begin{abstract}
Elberta' peaches (Prunus persica L.) harvested 6 days apart were treated with $0.5 \mathrm{~mL} \cdot \mathrm{L}^{-1} 1$-MCP for 4 hours at $20{ }^{\circ} \mathrm{C}$ then stored at $0,5,10$ or $20{ }^{\circ} \mathrm{C}$. Fruit were ripened at $20{ }^{\circ} \mathrm{C}$ for 3 days after 1,3 , and 6 weeks of storage at 0,5 , and $10{ }^{\circ} \mathrm{C}$. Treatment with 1-MCP delayed the onset of climacteric ethylene production and reduced respiration in fruit held at $20{ }^{\circ} \mathrm{C}$. 1-MCP-treated fruit were firmer than untreated controls after storage at 0 or $5{ }^{\circ} \mathrm{C}$. 1-MCP-treated fruit also had higher titratable acidity (TA) after 1 week of storage at 0 or $5^{\circ} \mathrm{C}$, but TA was lower compared to controls after 3 or 6 weeks of storage. Fruit stored at $5{ }^{\circ} \mathrm{C}$ had more severe internal browning, lower extractable juice and TA than fruit stored at either 0 or $10^{\circ} \mathrm{C}$, however, 1-MCP treated fruit had more severe internal browning than untreated fruit after 3 and 6 weeks of storage at $5{ }^{\circ} \mathrm{C}$. Fruit from harvest 1 treated with 1-MCP and stored at $0{ }^{\circ} \mathrm{C}$ for 6 weeks failed to soften after removal from storage. Chemical name used: 1-methylcyclopropene (1-MCP).
\end{abstract}

Peach is a climacteric fruit that exhibits a dramatic increase in ethylene production associated with changes in texture and flavor during ripening. Although refrigeration can be used to extend peach storage life, many cultivars are chilling sensitive. Symptoms of chilling injury (CI) include flesh browning, lack of juiciness (mealiness, wooliness, leatheriness), failure to ripen, lack of characteristic aroma and translucency of the flesh (Mitchell and Kader, 1989). Many factors affect the development of chilling injury including cultivar, harvest maturity and storage temperature (Eksteen, 1984; Von Mollendorff, 1987). Cultivars that ripen later in the season are generally more susceptible to CI, and susceptibility to CI decreases as fruit maturity advances (Von Mollendorff, 1987). Peaches stored at 3 to $5^{\circ} \mathrm{C}$ are most likely to develop CI (Anderson, 1979; Von Mollendorff and De Villiers, 1992).

The role of ethylene in development of peach CI symptoms is unclear. Ethylene exposure before storage delays CI symptoms (Von Mollendorff, 1987). However, storage in a high $\mathrm{CO}_{2}$ and low $\mathrm{O}_{2}$ controlled atmosphere (CA) that may reduce ethylene action also reduces CI symptoms (Eris et al., 1994; Nanos and Mitchell, 1991). Reduction of ethylene biosynthesis via the use of aminoethoxyvinylglycine or inhibition of ethylene action by high $\mathrm{CO}_{2}$ results in reduced soften-

Received for publication 28 Aug. 2000. Accepted for publication 6 June 2001 .

${ }^{1}$ Current address: USDA, ARS ERRC, 600 E. Mermaid Lane, Wyndmoor, PA 19038.

${ }^{2}$ Current address: Estacao Experimental de Cacador, CP 591, CEP: 89500-00, Cacador, SC, Brazil.

${ }^{3}$ To whom reprint requests should be addressed. Telephone: (509) 664-2280; fax (509) 664-2287; E-mail: mattheis@tfrl.ars.usda.gov ing (Byers, 1997; Kader et al., 1982; Nanos and Mitchell, 1991; Wankier et al., 1970). 1-MCP also inhibits ethylene action (Sisler and Blankenship, 1996; Sisler and Serek, 1997) and slows softening of various climacteric fruit (Abdi et al., 1998; Golding et al., 1998; Fan and Mattheis, 1999) including peach (Mathooko et al., 2001).

The objectives of this study were to investigate the effects of 1-MCP treatment and storage temperature on maintenance of peach fruit quality, and to examine the role of ethylene action in development of peach CI.

\section{Materials and Methods}

'Elberta' peach fruit were harvested from a commercial orchard near Wenatchee, Wash. in 1998. Fruit were harvested 105 and 111 days after full bloom (DAFB) to obtain fruit at two stages of maturation. Fruit quality was analyzed at harvest and after storage using 20 individual fruit replicates for each harvest $x$ treatment $\times$ storage temperature $\times$ storage $\mathrm{du}$ ration combination. Ground color $\left(\mathrm{L}^{*} \mathrm{a}^{*} \mathrm{~b}^{*}\right)$ was measured on the shade side of the fruit with a colorimeter (Minolta CR-200; Minolta Corp., Osaka, Japan) fitted with CIE illuminant $\mathrm{C}$ and an 8-mm measuring aperture. Hue was calculated from $\mathrm{a}^{*}$ and $\mathrm{b}^{*}$ values (McGuire, 1992). Fruit firmness was determined on opposite pared cheeks of 20 peaches using a Universal TA-XT2 texture analyzer (Texture Technologies Corp., Scarsdale, N.Y.) with a $0.79-\mathrm{cm}$-diameter cylindrical tip. Juice prepared using a Champion juicer (Plastaket Manufacturing Co., Lodi, Calif.) was used to determine titratable acidity (TA), soluble solids content (SSC) and mealiness index (extractable juice). TA was measured by titrating $10 \mathrm{~mL}$ juice with $0.1 \mathrm{~N} \mathrm{KOH}$ to $\mathrm{pH} 8.2$ and expressed as per- centage of malic acid. SSC was measured using an Atago N1 refractometer (Atago, Tokyo). The amount of extractable juice was determined by centrifuging $1 \mathrm{~g}$ of the homogenate for $15 \mathrm{~min}$ at $16,000 \mathrm{~g}$. The supernatant was decanted and then weighed. The amount $(\mathrm{g})$ of the supernatant was used as an index of mealiness.

1-MCP Treatment. Generation of 1-MCP was by addition of Ethylbloc (Floralife, Walterboro, S.C.) powder to a $1 \mathrm{~N} \mathrm{KOH}$ solution. Fruit were treated on the day of harvest with $0.5 \mu \mathrm{L} \cdot \mathrm{L}^{-1} 1-\mathrm{MCP}$ for $4 \mathrm{~h}$ at $20{ }^{\circ} \mathrm{C}$ in a sealed 230-L steel chamber. The concentration of 1-MCP in the chamber was measured using a gas chromatograph (GC, HP 5880; Agilent Technologies, Avondale, Pa.) equipped with a glass column (45-cm length, $0.32-\mathrm{cm}$ diameter) packed with Porapak Q, 80-100 mesh (Alltech Associates, Deerfield, Ill.). A $0.5-\mathrm{mL}$ sample of headspace was removed from the chamber and injected into the GC prior to unsealing the chamber at the end of the 4-h treatment period. Temperatures for the GC injector, oven, and flame ionization detector (FID) were 100,130 , and $200{ }^{\circ} \mathrm{C}$, respectively. Flow rates for $\mathrm{N}_{2}$ carrier, $\mathrm{H}_{2}$ and air were 25,30 and $300 \mathrm{~mL} \cdot \mathrm{min}^{-1}$, respectively. A 1-butylene standard (Scott, Plumsteadville, Pa.) was used to generate a response factor and 1-MCP quantification was based on this value.

Ethylene production and respiration rate. Fruit (4-4 fruit replicates, 800-900 g, per treatment) were enclosed in 12-L plexiglass chambers purged with compressed air at $6 \mathrm{~L} \cdot \mathrm{h}^{-1}$. Temperature of the chamber room was maintained at $20^{\circ} \mathrm{C}$. For $\mathrm{CO}_{2}$ analysis, gas samples $(1 \mathrm{~mL})$ withdrawn from each chamber outlet were injected into a HP 5890 GC (Agilent Technologies, Avondale, Pa.) equipped with a methanizer (John T. Booker, Austin, Texas) and a $60-\mathrm{cm}$ stainless steel column $(2-\mathrm{mm}$ ID) packed with Porapak Q (80/100 mesh). Oven, injector, and FID temperatures were 30 , 50 , and $200{ }^{\circ} \mathrm{C}$, respectively. Gas flows for $\mathrm{N}_{2}$ carrier gas, $\mathrm{H}_{2}$, and air were 65,30 , and 300 $\mathrm{mL} \cdot \mathrm{min}^{-1}$, respectively. Ethylene was analyzed in $0.5 \mathrm{~mL}$ gas samples injected into a HP 5880A $\mathrm{GC}$, with a $30-\mathrm{cm}$ glass column (3.2 mm ID) packed with Porapak Q (80/100 mesh). Oven, injector, and FID temperatures were 50,50, and $200^{\circ} \mathrm{C}$. Gas flows for $\mathrm{N}_{2}$ carrier gas, $\mathrm{H}_{2}$, and air were 30,30 , and $300 \mathrm{~mL} \cdot \mathrm{min}^{-1}$, respectively. $\mathrm{CO}_{2}$ and $\mathrm{C}_{2} \mathrm{H}_{4}$ were measured every 1 or $2 \mathrm{~d}$.

Fruit shelf life and post-storage quality. After 1-MCP treatment, fruit were stored at $20^{\circ} \mathrm{C}$ for $10 \mathrm{~d}$, or at 0,5 or $10^{\circ} \mathrm{C}$ for 1,3 , or 6 weeks plus an additional $3 \mathrm{~d}$ at $20^{\circ} \mathrm{C}$ before quality was determined. There were 20 fruits for each treatment $\times$ storage temperature $\times$ storage duration combination. Decay developed after 6 weeks of storage at $10{ }^{\circ} \mathrm{C}$ and limited the number of fruit usable for quality analyses. Internal browning was rated subjectively on the mesocarp surface immediately after cutting the fruit in half along the suture line. Browning was rated as: $1=$ none; $2=$ slight $; 3=$ moderate; and $4=$ severe

Experimental design and statistical analysis. The experiment was conducted using 
a factorial design with four factors: fruit maturity, 1-MCP treatment, storage temperature, storage duration. Data were subjected to statistical analysis using SAS ver. 6.12 (SAS Institute, Cary, N.C.). The effects of storage temperature and storage duration were analyzed using orthogonal comparisons. First, coefficients of polynomials were generated using the Proc IML procedure, and then significance of polynomials were calculated using the generated coefficients in Contrast statements of the GLM procedure of the SAS System. The effects of storage temperature, storage duration, maturity and 1-MCP were analyzed using analysis of variance (ANOVA).

\section{Results}

Indicators of fruit maturity at harvest 1 were (mean $\pm \mathrm{SE}$ ): firmness: $33.4 \pm 4.1 \mathrm{~N}$; SSC 9.9 $\pm 0.2 \%$; TA $0.49 \pm 0.02 \mathrm{~g} \cdot 100 \mathrm{~g}^{-1} ; \mathrm{L}^{*}$ $70.2 \pm 1.2$; and hue $89.2 \pm 1.2$. Values for harvest 2 fruit were: firmness $20.9+3.0 \mathrm{~N}$; SSC $9.8 \pm 0.2 \%$; TA $0.45 \pm 0.01 \mathrm{~g} \cdot 100 \mathrm{~g}^{-1} ; \mathrm{L}$ $73.6 \pm 0.5$; and hue $87.9 \pm 0.7$.

1-MCP effects on ethylene production and respiration rate. Ethylene production by fruit of both maturities treated with 1-MCP was transiently stimulated to a rate higher than controls for the first 2-3 d after treatment, the climacteric rise was delayed with lower peak production during the latter portion of the post-treatment period (Fig. 1). Respiration of $1-\mathrm{MCP}$ treated fruit was lower compared to that of untreated control fruit for the first $5 \mathrm{~d}$ after treatment for harvest 1 fruit and the first $8 \mathrm{~d}$ for harvest 2 fruit (Fig. 2).

Effects of 1-MCP on peach shelf life. Treatment of harvest 1 fruit with 1-MCP resulted in higher SSC and less peel color change during the 10 day posttreatment period at $20^{\circ} \mathrm{C}$, but, no treatment differences in firmness or TA were observed (Table 1). Harvest 2 fruit treated with 1-MCP had higher firmness and TA, but lower SSC, compared to untreated fruit $10 \mathrm{~d}$ after treatment when stored at $20^{\circ}$ (Table 1). There was no treatment effect on peel color.

Effects of 1-MCP on peach fruit quality after storage. With the exception of harvest 1 fruit stored at $0{ }^{\circ} \mathrm{C}$, most of the fruit softening occurring during storage and ripening took place in the first week after treatment (Table 2). Untreated fruit stored at $0{ }^{\circ} \mathrm{C}$ from harvest 1 did not soften between weeks 3 and 6 while 1-MCP-treated stored at both 0 and $5{ }^{\circ} \mathrm{C}$ did not soften during the entire 6-week storage period. Fruit treated with $1-\mathrm{MCP}$ then stored at 0 or $5{ }^{\circ} \mathrm{C}$ were firmer compared to untreated fruit regardless of storage duration. Firmness of the 1-MCP treated fruit from harvest 1 was 3 times that of controls after 3 weeks of storage at $0{ }^{\circ} \mathrm{C}$. Fruit firmness generally decreased with increased storage temperature, but, higher firmness values after longer storage durations indicated that fruit failed to ripen. Firmness varied most for harvest 1 fruit after storage.

Fruit TA generally decreased with increased storage duration regardless of harvest maturity or storage temperature (Table 3 ). The one exception was fruit stored at $10{ }^{\circ} \mathrm{C}$ for 3 weeks. However, storage temperature influenced the magnitude of TA loss. Fruit stored at $5{ }^{\circ} \mathrm{C}$ frequently had the lowest TA, especially after 3 and 6 weeks of storage for fruit from both harvest dates. 1-MCP treatment slowed TA loss by fruit from the second harvest at all temperatures after 1 week of storage. Fruit treated with 1-MCP and stored at $5{ }^{\circ} \mathrm{C}$ had lower TA compared to controls after both 3 and 6 weeks of storage. Fruit SSC did not change consistently during cold storage at any temperature and was not consistently affected by 1 -MCP treatment or storage duration (data not shown).

Hue values of control fruit from harvest 1 did not change during storage while hue of 1-MCP-treated fruit decreased linearly regardless of storage temperature, resulting in

Table 1. Quality of control (C) and 1-MCP-treated 'Elberta' peach fruit after $10 \mathrm{~d}$ storage at $20^{\circ} \mathrm{C}$. Fruit were treated with $0.5 \mathrm{~mL} \cdot \mathrm{L}^{-1} 1-\mathrm{MCP}$ on the day of harvest, (harvest 1, 105 DAFB; harvest 2,111 DAFB) then stored for $10 \mathrm{~d}$ at $20^{\circ} \mathrm{C} . \mathrm{n}=20$.

\begin{tabular}{lcccc}
\hline \hline Treatment & Firmness & SSC \\
$(\mathrm{N})$ & $(\%)$ & TA \\
$\left(\mathrm{g} \cdot 100 \cdot \mathrm{g}^{-1}\right)$ & Hue \\
\hline \multicolumn{5}{c}{ Harvest 1 } \\
$\mathrm{CK}$ & $3.6 \mathrm{a}^{\mathrm{a}}$ & $9.3 \mathrm{~b}$ & $0.346 \mathrm{a}$ & $76.5 \mathrm{~b}$ \\
$\mathrm{MCP}$ & $4.0 \mathrm{a}$ & $9.8 \mathrm{a}$ & $0.374 \mathrm{a}$ & $81.1 \mathrm{a}$ \\
\multicolumn{5}{c}{ Harvest 2} \\
$\mathrm{CK}$ & $3.4 \mathrm{~b}$ & $10.0 \mathrm{a}$ & $0.361 \mathrm{~b}$ & $78.4 \mathrm{a}$ \\
$\mathrm{MCP}$ & $4.4 \mathrm{a}$ & $9.4 \mathrm{~b}$ & $0.412 \mathrm{a}$ & $78.9 \mathrm{a}$
\end{tabular}

${ }^{2}$ Means with same letter are not significantly different (LSD, $P \leq 0.05$ ). Comparison within same maturity.

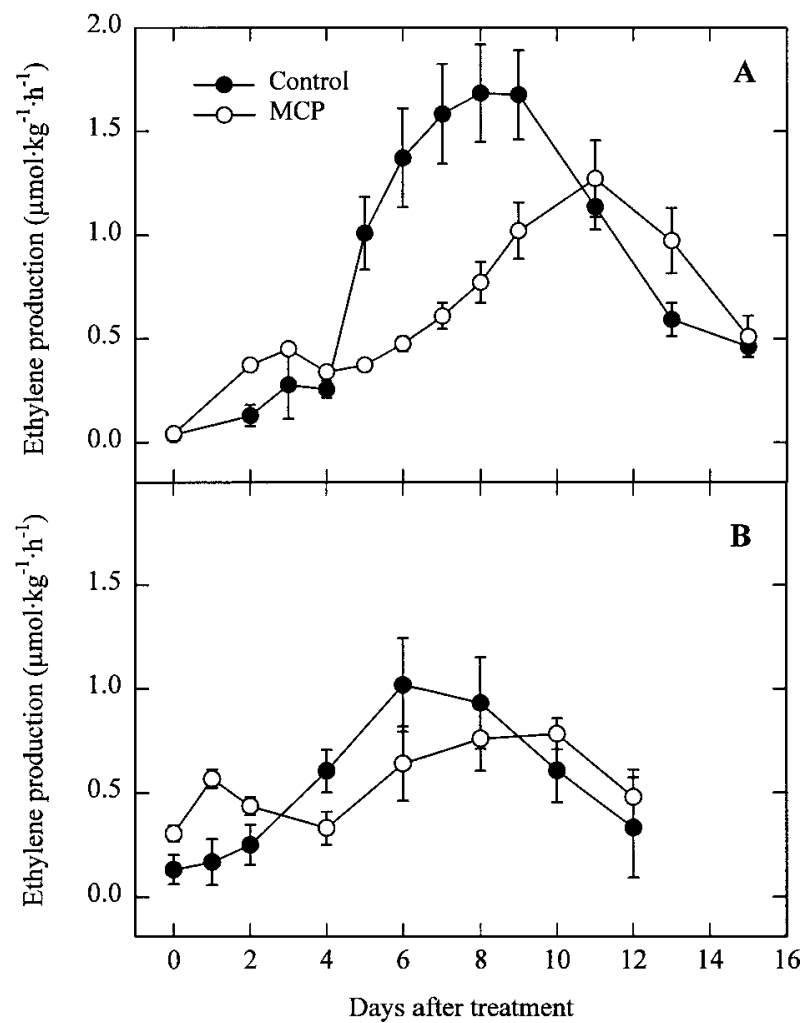

Fig. 1. (A) Harvest 1. (B) Harvest 2. Effect of 1-MCP on ethylene production of 'Elberta' peach fruit stored at $20{ }^{\circ} \mathrm{C}$. Fruit were treated with $0.5 \mathrm{~mL} \cdot \mathrm{L}^{-1}$ 1 -MCP for $4 \mathrm{~h}$ at $20^{\circ} \mathrm{C}$. Vertical bars represent SD of means of four replicates.

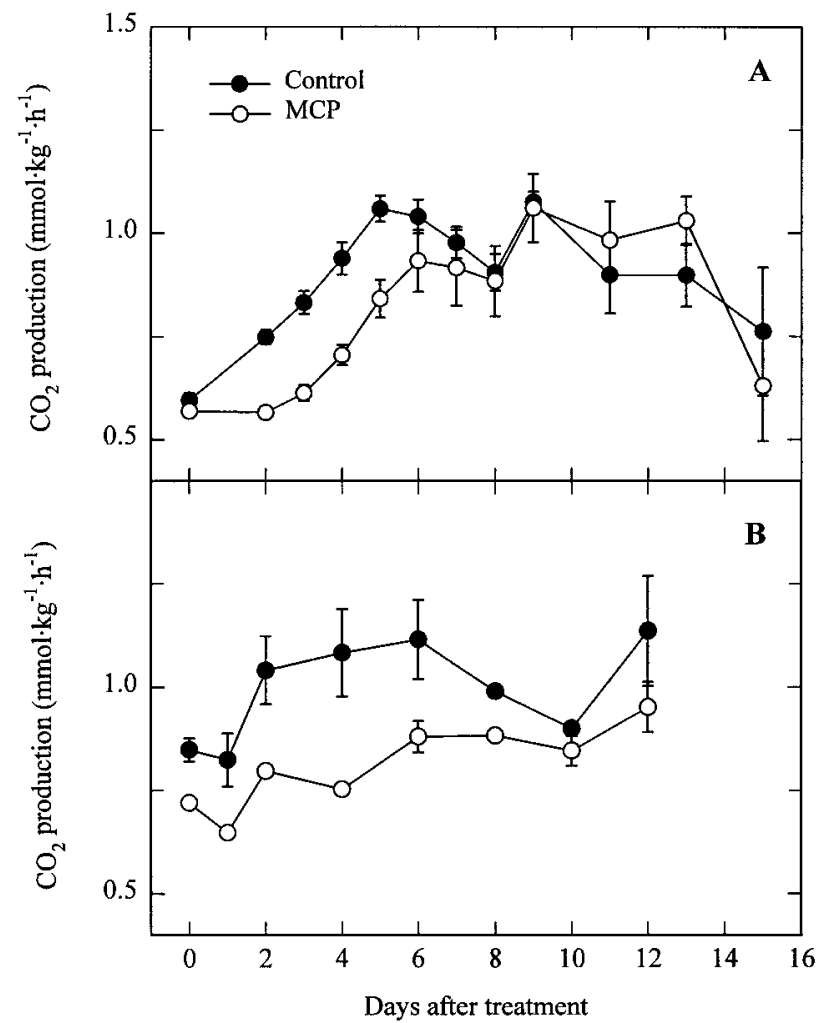

Fig. 2. (A) Harvest 1. (B) Harvest 2. Effect of 1-MCP on respiration rate of 'Elberta' peach fruit stored at $20{ }^{\circ} \mathrm{C}$. Fruit were treated with $0.5 \mathrm{~mL} \cdot \mathrm{L}^{-1}$ 1 -MCP for $4 \mathrm{~h}$ at $20^{\circ} \mathrm{C}$. Vertical bars represent SD of means of four replicates. 
lower hue values of 1-MCP-treated fruit after 3 or 6 weeks of storage (Table 4). There were no changes in hue values of harvest 2 fruit during storage.

The weight of extractable juice was affected by storage temperature (Table 5). Fruit stored at $5{ }^{\circ} \mathrm{C}$ usually had the lowest amount of extractable juice, but treatment with 1-MCP did not consistently reduce or increase the amount of extractable juice. The amount of extractable juice from harvest 2 fruit decreased during storage at 0 and $5{ }^{\circ} \mathrm{C}$. Although there were differences in extractable juice volume based on storage temperature, none of the fruit were particularly mealy.

The majority of internal browning that developed in fruit from both harvests occurred between 3 and 6 weeks of storage (Table 6) although browning was present in 1-MCP-treated fruit stored at $5{ }^{\circ} \mathrm{C}$ for 3 weeks plus $3 \mathrm{~d}$ at $20{ }^{\circ} \mathrm{C}$ (data not shown).
Fruit stored at $5{ }^{\circ} \mathrm{C}$ generally had the most internal browning. Fruit treated with 1-MCP and stored at $5{ }^{\circ} \mathrm{C}$ had the most internal browning. These fruit also developed external browning between 3 and 6 weeks in storage (data not shown).

\section{Discussion}

Climacteric ethylene production is accompanied by softening in ripening peach fruit. Peach ripening occurs in two phases with a slight rise in ethylene production and slow softening followed by a high rate of ethylene production and rapid softening (Tonutti et al., 1996). Our results indicate 1-MCP treatment may have stimulated ethylene production in the first phase of ripening while inhibiting production during the second phase (Fig. 1). However, 1-MCP treatment inhibited fruit respiration in both phases, suggesting that

Table 2. Firmness (N) of control (C) and 1-MCP-treated 'Elberta' peach fruit after 1, 3, and 6 weeks storage at 0,5 , or $10^{\circ} \mathrm{C}$ plus $3 \mathrm{~d}$ at $20^{\circ} \mathrm{C} . \mathrm{n}=20$.

\begin{tabular}{|c|c|c|c|c|c|c|c|c|c|}
\hline \multirow[b]{3}{*}{ Temp $\left({ }^{\circ} \mathrm{C}\right)$} & \multicolumn{6}{|c|}{ Storage duration (weeks) } & \multicolumn{3}{|c|}{ Storage duration } \\
\hline & \multicolumn{2}{|r|}{1} & \multicolumn{2}{|c|}{3} & \multicolumn{2}{|r|}{6} & \multirow[b]{2}{*}{$\operatorname{LSD}^{2}$} & \multicolumn{2}{|c|}{$\mathrm{L}^{\mathrm{y}}$} \\
\hline & $\mathrm{C}$ & 1-MCP & $\mathrm{C}$ & 1-MCP & $\mathrm{C}$ & 1-MCP & & $\mathrm{C}$ & 1-MCP \\
\hline \multicolumn{10}{|c|}{ Harvest 1} \\
\hline 0 & 5.5 & 7.1 & 5.6 & 17.4 & 18.1 & 20.0 & 4.0 & * & $*$ \\
\hline 5 & 5.3 & 6.3 & 4.0 & 7.5 & 5.4 & 9.5 & 1.6 & \multirow{3}{*}{$*$} & $*$ \\
\hline 10 & 4.1 & 4.8 & 3.2 & 2.8 & 2.5 & 3.0 & \multirow[t]{2}{*}{0.5} & & $*$ \\
\hline $1-\mathrm{MCP}^{\mathrm{x}}$ & \multicolumn{6}{|c|}{$*$} & & & \\
\hline \multicolumn{10}{|c|}{ Temperature } \\
\hline LSD & 0.8 & 2.0 & 1.6 & 5.1 & 5.4 & 5.9 & & & \\
\hline $\mathrm{L}$ & $*$ & $*$ & $*$ & $*$ & $*$ & $*$ & & & \\
\hline \multicolumn{10}{|c|}{ Harvest 2} \\
\hline 0 & 3.3 & 5.4 & 3.8 & 5.0 & 5.2 & 6.2 & 0.9 & $*$ & \\
\hline 5 & 3.5 & 4.5 & 4.1 & 5.9 & 4.4 & 5.6 & 0.7 & $*$ & \\
\hline 10 & 3.5 & 4.0 & 2.7 & 2.9 & 3.2 & 3.3 & 0.4 & * & \\
\hline 1-MCP & \multicolumn{2}{|r|}{$*$} & \multicolumn{2}{|r|}{$*$} & \multicolumn{2}{|r|}{$*$} & & & \\
\hline \multicolumn{10}{|l|}{ Temperature } \\
\hline LSD & 0.6 & 0.7 & 0.8 & 1.3 & 1.0 & 1.0 & & & \\
\hline $\mathrm{L}$ & & $*$ & $*$ & $*$ & * & $*$ & & & \\
\hline
\end{tabular}

${ }^{2}$ Least significant difference (LSD), $P \leq 0.05$.

${ }^{y}$ Significant linear regression, $P \leq 0.05 \%(*)$.

${ }^{\times}$Significant LSD, $P \leq 0.05 \%(*)$.

Table 3. Titratable acidity $\left(\mathrm{g} \cdot 100 \cdot \mathrm{g}^{-1}\right)$ of control $(\mathrm{C})$ and 1-MCP-treated 'Elberta' peach fruit after 1, 3, and 6 weeks of storage at 0,5 , or $10^{\circ} \mathrm{C}$ plus $3 \mathrm{~d}$ at $20^{\circ} \mathrm{C} . \mathrm{n}=20$.

\begin{tabular}{|c|c|c|c|c|c|c|c|c|c|}
\hline \multirow[b]{3}{*}{ Temperature $\left({ }^{\circ} \mathrm{C}\right)$} & \multicolumn{6}{|c|}{ Storage duration (weeks) } & \multirow{2}{*}{\multicolumn{3}{|c|}{$\frac{\text { Storage duration }}{\mathrm{L}^{\mathrm{y}}}$}} \\
\hline & \multicolumn{2}{|c|}{1} & \multicolumn{2}{|c|}{3} & \multicolumn{2}{|c|}{6} & & & \\
\hline & $\mathrm{C}$ & $1-\mathrm{MCP}$ & $\mathrm{C}$ & $1-\mathrm{MCP}$ & $\mathrm{C}$ & $1-\mathrm{MCP}$ & $\mathrm{LSD}^{\mathrm{z}}$ & $\mathrm{C}$ & 1-MCP \\
\hline \multicolumn{10}{|c|}{ Harvest 1} \\
\hline 0 & 0.425 & 0.409 & 0.422 & 0.377 & 0.380 & 0.327 & 0.021 & * & * \\
\hline 5 & 0.339 & 0.365 & 0.345 & 0.279 & 0.275 & 0.226 & 0.026 & $*$ & * \\
\hline 10 & 0.366 & 0.360 & 0.422 & 0.363 & 0.287 & 0.296 & 0.026 & $*$ & $*$ \\
\hline $1-\mathrm{MCP}^{\mathrm{x}}$ & \multicolumn{6}{|c|}{$*$} & & & \\
\hline \multicolumn{10}{|l|}{ Temperature } \\
\hline LSD & 0.043 & 0.022 & 0.036 & 0.028 & 0.037 & 0.029 & & & \\
\hline $\mathrm{L}$ & $*$ & & & $*$ & & & & & \\
\hline \multicolumn{10}{|c|}{ Harvest 2} \\
\hline 0 & 0.338 & 0.402 & 0.356 & 0.421 & 0.306 & 0.354 & 0.022 & * & $*$ \\
\hline 5 & 0.334 & 0.367 & 0.367 & 0.318 & 0.180 & 0.135 & 0.017 & $*$ & $*$ \\
\hline 10 & 0.326 & 0.389 & 0.389 & 0.310 & 0.234 & 0.229 & 0.017 & $*$ & $*$ \\
\hline 1-МCP & \multicolumn{4}{|c|}{$*$} & & & & & \\
\hline \multicolumn{10}{|l|}{ Temperature } \\
\hline LSD & 0.021 & 0.021 & 0.023 & 0.026 & 0.023 & 0.026 & & & \\
\hline $\mathrm{L}$ & & * & $*$ & * & $*$ & * & & & \\
\hline
\end{tabular}

${ }^{2}$ Least significant difference (LSD), $P \leq 0.05$.

${ }^{\mathrm{y}}$ Significant linear regression, $P \leq 0.05 \%(*)$.

${ }^{x}$ Significant LSD, $P \leq 0.05 \%$ (*). there is a differential response of ethylene and respiration to 1-MCP in 'Elberta' peach fruit. 'Hakuho' peach fruit treated at a lower (20 $\left.\eta \mathrm{L} \cdot \mathrm{L}^{-1}\right)$ 1-MCP concentration did not exhibit an initial increase in ethylene production (Mathooko et al., 2001) indicating there may be some differences in how various peach cultivars respond to $1-\mathrm{MCP}$. Our results also indicate 1-MCP treatment altered 'Elberta' fruit ripening during storage. 1-MCP-treated fruit usually had higher firmness compared to controls, a result similar to that of 'Hakuho' peach fruit (Mathooko et al., 2001). Fruit treated with 1-MCP also had higher TA than controls after $10 \mathrm{~d}$ at $20^{\circ} \mathrm{C}$ and after 1 -week storage at 0,5 , or $10^{\circ} \mathrm{C}$ plus $3 \mathrm{~d}$ at $20^{\circ} \mathrm{C}$. The inhibition of ripening by $1-\mathrm{MCP}$ has been observed on many other climacteric fruits (Abdi et al., 1998; Fan et al., 1999; Golding et al., 1998).

Although low temperature storage of peach fruit can extend storage life, development of CI can also occur. Peach CI symptoms include failure to ripen, development of internal and external browning, and mealiness. In the present experiments, peaches stored at $0{ }^{\circ} \mathrm{C}$ for 1 week and then held for $3 \mathrm{~d}$ at $20^{\circ} \mathrm{C}$ ripened normally as indicated by flesh softening, but after 6 weeks of storage plus $3 \mathrm{~d}$ at $20^{\circ} \mathrm{C}$, fruit failed to soften. The failure to soften was pronounced in fruit from the first harvest, and was consistent with previous reports that the failure to soften after prolonged cold storage is maturity-dependent (Kosiyachinda and Young, 1976; Robertson et al., 1992).

The peach fruit used in these studies developed different $\mathrm{CI}$ symptoms at different storage temperatures. Peaches stored at $0{ }^{\circ} \mathrm{C}$ failed to soften and developed internal and external browning during 6 weeks of storage. Storage at $5{ }^{\circ} \mathrm{C}$ resulted in the most severe development of internal and external browning and development of mealiness. These results confirm earlier observations that fruit stored at $5{ }^{\circ} \mathrm{C}$ develop more internal browning than when stored at $0{ }^{\circ} \mathrm{C}$ (Anderson, 1979; Nanos and Mitchell, 1991; Von Mollendorff and De Villiers, 1992).

Lower TA preceded the appearance of internal and external browning. For example, lower TA was observed after 1 week of storage at $5{ }^{\circ} \mathrm{C}$ while internal and external browning were observed after 6 weeks of storage. A simple method for indexing or predicting the severity of CI could possibly be based on respiration rate and TA (Picha, 1987; Raison, 1980), however, due to the climacteric nature of peach fruit, TA may be a more reliable index for predicting CI symptoms.

The amount of extractable juice, used as an index of mealiness (Lill and Van Der Mespel, 1988), was lowest in fruit stored at $5{ }^{\circ} \mathrm{C}$ in our study. Treatment with 1-MCP had no effect on the amount of extractable juice. Mealiness has been associated with impaired degradation of pectin, accumulation of insoluble pectin of high molecular weight (Ben-Arie and Lavee, 1971; Dawson et al., 1992), and abnormal changes in cell wall structure (Brovelli et al., 1998; Luza et al., 1992). Fruit stored at 
Table 4. Hue value of control (C) and 1-MCP-treated 'Elberta' peach fruit after 1, 3, and 6 weeks storage at 0,5 , or $10^{\circ} \mathrm{C}$ plus $3 \mathrm{~d}$ at $20^{\circ} \mathrm{C} . \mathrm{n}=20$.

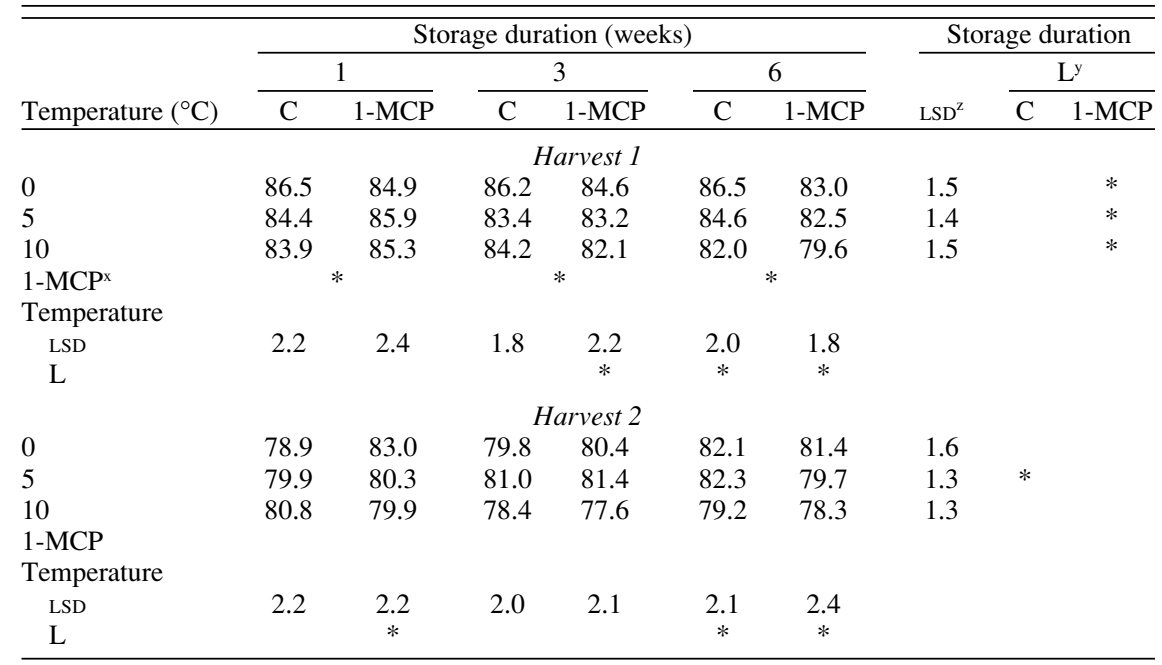

${ }^{2}$ Least significant difference (LSD), $P \leq 0.05$.

'Significant linear regression, $P \leq 0.05 \%$ (*).

${ }^{\mathrm{x}}$ Significant LSD, $P \leq 0.05 \%(*)$.

Table 5. The amount (g) of extractable juice from control (C) and 1-MCP-treated 'Elberta' peach fruit after 1,3 , and 6 weeks storage at 0,5 , or $10^{\circ} \mathrm{C}$ plus $3 \mathrm{~d}$ at $20^{\circ} \mathrm{C}$. One gram juice was centrifuged at $16,000 \mathrm{~g}$ for $15 \mathrm{~min}$, then the clear supernatant was decanted and weighed. $\mathrm{n}=20$.

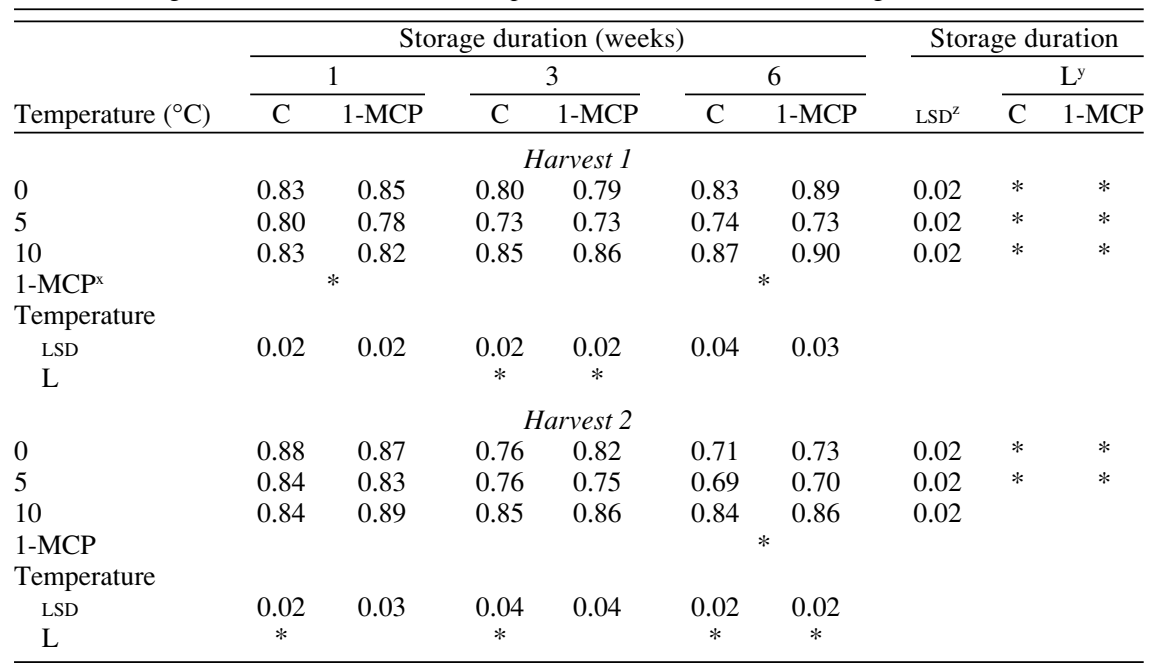

${ }^{2}$ Least significant difference (LSD), $P \leq 0.05$.

${ }^{y}$ Significant linear regression, $P \leq 0.05 \%(*)$.

${ }^{\times}$Significant LSD, $P \leq 0.05 \%(*)$.

$5{ }^{\circ} \mathrm{C}$ have more severe mealiness than when stored at $0{ }^{\circ} \mathrm{C}$ (Anderson, 1979; Von Mollendorff, 1987). Although 1-MCP did not impact the amount of extractable juice, fruit treated with 1-MCP had increased CI incidence. For example, 1-MCP-treated fruit stored at $5{ }^{\circ} \mathrm{C}$ had severe internal browning compared to controls. Fruit treated with 1-MCP were always firmer compared with untreated control fruit regardless of storage duration or storage temperature. Fruit firmness values indicated the fruit's failure to ripen. It has been shown that ethylene exposure before storage reduces CI of peaches (Von Mollendorff, 1987), and 1-MCP increased chilling injury severity of oranges, a nonclimacteric fruit (Porat et al., 1999). Together, these results indicate ethylene plays a role in development of $\mathrm{CI}$ in both climacteric and non-climacteric fruit, and the inhibition of ethylene action

increases fruit susceptibility to low temperature injury.

In summary, 1-MCP appears to have limited effects on slowing ripening of peach fruit. Storage temperature and maturity at harvest had more profound effect on many aspects of storage quality of peach than 1-MCP. Although 1-MCP inhibited peach ripening when fruit were stored at $20{ }^{\circ} \mathrm{C}$, more CI developed in 1-MCP-treated fruit stored at low temperatures.

\section{Literature Cited}

Abdi, N., W.B. McGlasson, P. Holford, M. Williams, and Y. Mizrahi. 1998. Response of climacteric and suppressed-climacteric plums to treatment with propylene and 1-methylcyclopropene. Postharvest Biol. Technol. 14:29-39.

Anderson, R.E. 1979. The influence of storage temperature and warming during storage on
Table 6. Internal browning of control (C) and 1-MCPtreated 'Elberta' peach fruit after 6 weeks of storage at 0,5 , or $10^{\circ} \mathrm{C}$ plus $3 \mathrm{~d}$ at $20^{\circ} \mathrm{C}$. Internal browning was rated subjectively as: $1=$ none, 2 = slight, $3=$ moderate, and $4=$ severe. $n=20$.

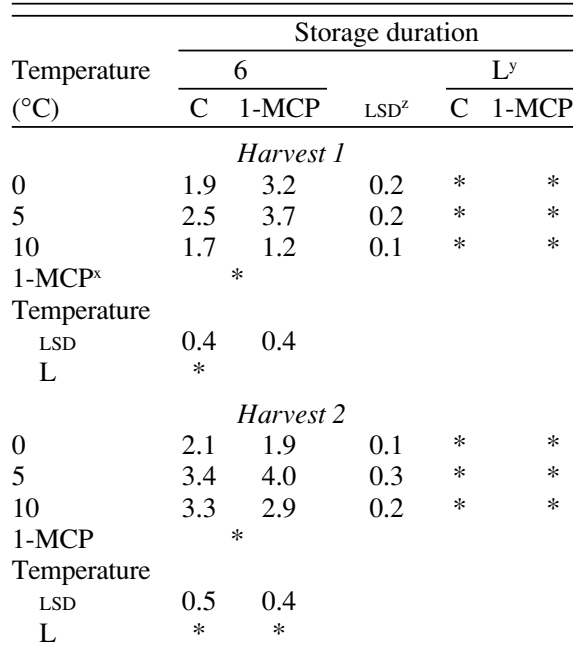

${ }^{2}$ Least significant difference (LSD), $P \leq 0.05$.

${ }^{y}$ Significant linear regression, $P \leq 0.05 \%(*)$.

${ }^{x}$ Significant LSD, $P \leq 0.05 \%$ (*).

peach and nectarine fruit quality. J. Amer. Soc. Hort. Sci. 104:459-461.

Ben-Arie, R. and S. Lavee. 1971. Pectic changes occurring in Elberta peaches suffering from woolly breakdown. Phytochemistry 10:531-538.

Brovelli, E.A., J.K. Brecht, and W. B. Sherman. 1998. Anatomical and physiological responses of melting- and nonmelting-flesh peaches to postharvest chilling. J. Amer. Soc. Hort. Sci. 123:668-674.

Byers, R.E. 1997. Peach and nectarine fruit softening following aminoethoxyvinylglycine sprays and dips. HortScience 32:86-88.

Dawson, D.M., L.D. Melton, and C.B. Watkins. 1992. Cell wall changes in nectarines (Prunus persica). Plant Physiol. 100:1203-1210.

Eksteen, G.J. 1984. A summary of recent research on woolliness in locally grown nectarines. Deciduous Fruit Grower. 34:389-392.

Eris, A., C. Turkben, M.H. Ozer, and J. Henze. 1994. Research on controlled atmosphere storage of peach cv. Hale Haven. Acta Hort. 368:1994.

Fan, X. and J.P. Mattheis. 1999. Methyl jasmonate promotes degreening of apple fruit independent of ethylene action. HortScience 34:310312.
Fan, X., S. Blankenship, and J.P. Mattheis. 1999. MCP inhibits apple fruit ripening. J. Amer. Soc Hort. Sci. 124:690-695.

Golding, J.B., D. Shearer, S.G. Wyllie, and W.B. McGlasson. 1998. Application of 1-MCP and propylene to identify ethylene-dependent ripening processes in mature banana fruit. Postharvest Biol. Technol. 14:87-98.

Kader, A.A., M.A. El-Goorani, and N.F. Sommer. 1982. Postharvest decay, respiration, ethylene production, and quality of peaches held in controlled atmospheres with added carbon monoxide. J. Amer. Soc. Hort. Sci. 107:856-859.

Kosiyachinda, S. and R.E. Young. 1976. Chilling sensitivity of avocado fruit at different stages of respiratory climacteric. J. Amer. Soc. Hort. Sci. 101:665-667.

Lill, R.E. and G.J. Van Der Mespel. 1988. A method for measuring the juice content of mealy nectarines. Sci. Hort. 36:267-271.

Luza, L.G., R. van Gorsel, V.S. Polito, and A.A. 
Kader. 1992. Chilling injury in peaches: A cytochemical and ultrastructural cell wall study. J. Amer. Soc. Hort. Sci. 117:114-118.

Mathooko, F.M., Y. Tsunashima, W.Z.O. Owino, and A. Inaba. 2001. Regulation of genes encoding ethylene biosynthetic enzymes in peach (Prunus persica L.) fruit by carbon dioxide and 1-methylcyclopropene. Postharvest Biol. Technol. 21:265-281.

McGuire, R.G. 1992. Reporting of objective color measurements. HortScience 27:1254-1255.

Mitchell, F.G. and A.A. Kader. 1989. Factors affecting deterioration rate. In: J.H. LaRue and R.S. Johnson (eds.). Peaches, plums, and nectarinesGrowing and handling for fresh market. Publ. 3331, Univ. of California, Div. of Agr. and Natural Resources, Oakland, p. 65-178.

Nanos, G.D. and F.G. Mitchell. 1991. High-temperature conditioning to delay internal breakdown development in peaches and nectarines. HortScience 26:882-885.

Picha, D.H. 1987. Chilling injury, respiration, and sugar changes in sweet potatoes stored at low temperature. J. Amer. Hort. Sci. 112:497-502.

Porat, R., B. Weiss, L. Cohen, A. Daus, R. Goren, and S. Droby. 1999. Effects of ethylene and 1-methylcyclopropene on the postharvest qualities of 'Shamouti' oranges. Postharvest Biol. Technol. 15:155-163.

Raison, J.K. 1980. Effect of low temperature on respiration. In: (eds.). The biochemistry of Plants P.K. Stumpf and E.E. Conn. Vol. 2, p. 613-626.

Robertson, J.A., F.I. Meredith, B.G., Lyon, G.W Chapman, and W.B. Sherman. 1992. Ripening and cold storage changes in the quality characteristics of non-melting clingstone peaches (FLA 9-20C). J. Food Sci. 57:462-465.

Sisler, E.C. and S.M. Blankenship. 1996. Method of counteracting an ethylene response in plants. U.S. Patent No. 5,518,988.

Sisler, E.C. and M. Serek. 1997. Inhibitors of ethylene responses in plants at the receptor level: Recent developments. Physiol. Plant.
100:577-582.

Tonutti, P., C. Bonghi, and A. Ramina. 1996. Fruit firmness and ethylene biosynthesis in three cultivars of peach (Prunus persica L. Batsch). J. Hort. Sci. 71:141-147.

Von Mollendorff, L.J. 1987. Woolliness in peach and nectarines: A review. 1. Maturity and external factors. Hort. Sci. 5:1-3.

Von Mollendorff, L.J. and O.T. De Villiers. 1988. Physiological changes associated with the development of woolliness in 'Peregrine' peaches during low-temperature storage. J. Hort. Sci. 6347-51.

Von Mollendorff, L.J. and O.T. De Villiers. 1992. Effect of temperature manipulation during storage and ripening on firmness, extractable juice and woolliness in nectarines. J. Hort. Sci. 67:655-662.

Wankier, B.N., D.K. Salunkhe, and W.F. Campbell. 1970. Effects of controlled atmosphere storage on biochemical changes in apricot and peach fruit. J. Amer. Soc. Hort. Sci. 95:604-609. 